\title{
RELIABILITY AND SAFETY AS AN OBJECTIVE OF INTELLIGENT TRANSPORT SYSTEMS IN URBAN AREAS
}

\section{NIEZAWODNOŚĆ I BEZPIECZEŃSTWO CELEM WDRAŻANIA INTELIGENTNYCH SYSTEMÓW TRANSPORTU W MIASTACH}

\author{
Jacek Oskarbski, Kazimierz Jamroz \\ Gdansk University of Technology \\ email: joskar@pg.gda.pl,kjamroz@pg.gda.pl
}

\begin{abstract}
Technologies that use transport telematics offer tools for strengthening urban transport systems. They rationalise the use of the existing infrastructure and transport management systems, increase their reliability and safety and improve the transport behaviour of residents, while reducing the operating costs of transport. The main reason for using Intelligent Transport Systems (ITS) is the need to implement measures to reduce the negative effects of growing motorization and improve the quality of transport services in response to the fluctuating transport demand. The authors present ways to improve the reliability and safety of transport in the street network by using ITS solutions.
\end{abstract}

Keywords: Intelligent Transport Systems, transport systems reliability

Streszczenie: Technologie, korzystajace z telematyki transportu oferuja narzędzia do wzmocnienia systemów transportowych $w$ miastach poprzez racjonalizacje wykorzystania istniejącej infrastruktury $i$ systemów zarządzania transportem, zwiększenie poziomu ich niezawodności i bezpieczeństwa, wplywając pozytywnie na zmiane zachowań transportowych mieszkańców przy jednoczesnym obniżeniu kosztów funkcjonowania transportu. Gtównym powodem stosowania inteligentnych systemów transportowych (ITS) jest potrzeba wdrożenia środków, które pozwola na redukcje negatywnych skutków rozwoju motoryzacji i przyczynia się do wzrostu jakości ustug transportowych $w$ warunkach zmiennego zapotrzebowania na transport. $W$ referacie przedstawiono możliwości podniesienia poziomu niezawodności i bezpieczeństwa transportu $w$ sieci ulicznej poprzez zastosowanie rozwiąań z zakresu Inteligentnych Systemów Transportu.

Stowa kluczowe: Inteligentne Systemy Transportu, niezawodność transportu 
Reliability and safety as an objective of intelligent transport systems in urban areas Niezawodność i bezpieczeństwo celem wdrażania inteligentnych systemów...

\section{Introduction}

Transport in urban areas is characterized by the simultaneous occurrence of multiple transport modes and a variety of needs of different user groups. Cities are areas of concentration of economic and social activities that are strictly conditional on the effectiveness of the transport system, including private and public transport and freight transport. The increasing demand for transport causes problems due to high concentration of transport in specific areas, the emergence of congestion and competition between different transport modes for limited resources in the infrastructure. A well-functioning urban transport system should meet the needs of all groups of users such as the residents, businesses and other institutions. According to the concept of city logistics such solutions should optimise the movement of persons, goods and streams of information and minimise the adverse impact of transport on the environment. Transport management in urban areas should be based on two basic assumptions to achieve these objectives. First, it is necessary to diagnose the operating problems of the urban transport system and select appropriate solutions in the area of infrastructure and organization the demand for transport. Second, tools must be selected to carry out these tasks. They should help to control and monitor selected aspects of urban transport and connect different actions on an operational and technical level. The solutions offered by Intelligent Transportation Systems support the practical implementation of planned activities by combining the two pillars (infrastructural and organizational) of logistics management in urban transport [1].

Transport management systems that use modern technologies provide better management of the existing transport infrastructure. American and European studies proved that ITS solutions offer significant benefits [2]. These include less congestion, better safety, more efficient transport (e.g. in terms of travel time), lower environmental impact, more comfort for transport users, improved economic performance of transport processes, less wear and tear on the infrastructure and better use of transport infrastructure. New ITS solutions both in urban areas and on motorways in Poland are currently under way. Such implementations provide opportunities to develop solutions that will ensure better reliability and safety of transport systems. The Tri-City Conurbation (Gdansk, Gdynia, Sopot) authorities decided to implement an Intelligent Transport System (ITS) in 2002, when scientists from the Gdansk University of Technology began conceptual work on the Integrated Transport Management System TRISTAR. After years of work, the project received funding from the Operational Programme Infrastructure and Environment. As a result, steps were taken that will result in the completion of the first stages of TRISTAR implementation in 2015. 


\section{Architecture of TRISTAR}

Analysis of Tri-City Conurbation transport systems identified a number of transport problems. They are [3]:

- high level of congestion, negatively affecting the conditions and quality of travel both for individual and public transport, loss of time and negative impact on the environment, in particular during peak times,

- with more social and business activity, mobility and traffic in the Tri-City Conurbation are rising too, making traffic conditions more difficult, while the existing road infrastructure, traffic systems and control do not meet the needs of the volumes and types of traffic.

- lack of parking space management, in particular in central areas, leading to congestion caused by driving in search of parking spaces,

- high costs of incidents and high costs incurred when the street network is congested as a result of road incidents,

- rescue operations are affected because of the difficulty with identifying the scene of the incident, reaching it and providing help,

- public transport is not prioritized in traffic, increasing travel times and making public transport less attractive compared to the use of private cars,

- poor information about traffic and driving conditions both before and during travel.

The decision was made to implement the ITS in the Tri-City Conurbation to solve the problems mentioned above. The Tri- City Conurbation (Gdansk, Gdynia, Sopot) authorities decided to implement an Intelligent Transport System (ITS) in 2002, when scientists from the Gdansk University of Technology began conceptual work on the Integrated Transport Management System TRISTAR. After years of work, the project received funding from the Operational Programme Infrastructure and Environment. As a result, steps were taken that will result in the completion of the first stages of TRISTAR implementation in 2015. The project has been developed within key elements defined in the TRISTAR system architecture, including the basic layout of the Tri-city street (Fig. 1) with about 150 intersections and pedestrian crossings equipped with traffic signals, communication infrastructure (including fibre optic cable) about $100 \mathrm{~km}$ long, installation of 60 video surveillance cameras (CCTV), 60 cameras to identify vehicles (ANPR), about 70 variable message signs at public transport stops, more than 20 variable message signs (VMS) and variable message boards (VMB) for drivers and equipping nearly 700 public transport vehicles with position transmitters and onboard computers [4]. The final system will be expanded and will include all junctions equipped with traffic signals. It will be integrated with the future National Traffic Management System foreseen to be implemented on express roads (Tri-city Ring Road, South Ring Road) as well as with systems for airports, rail and Tri-City sea ports. 
Reliability and safety as an objective of intelligent transport systems in urban areas Niezawodność i bezpieczeństwo celem wdrażania inteligentnych systemów...

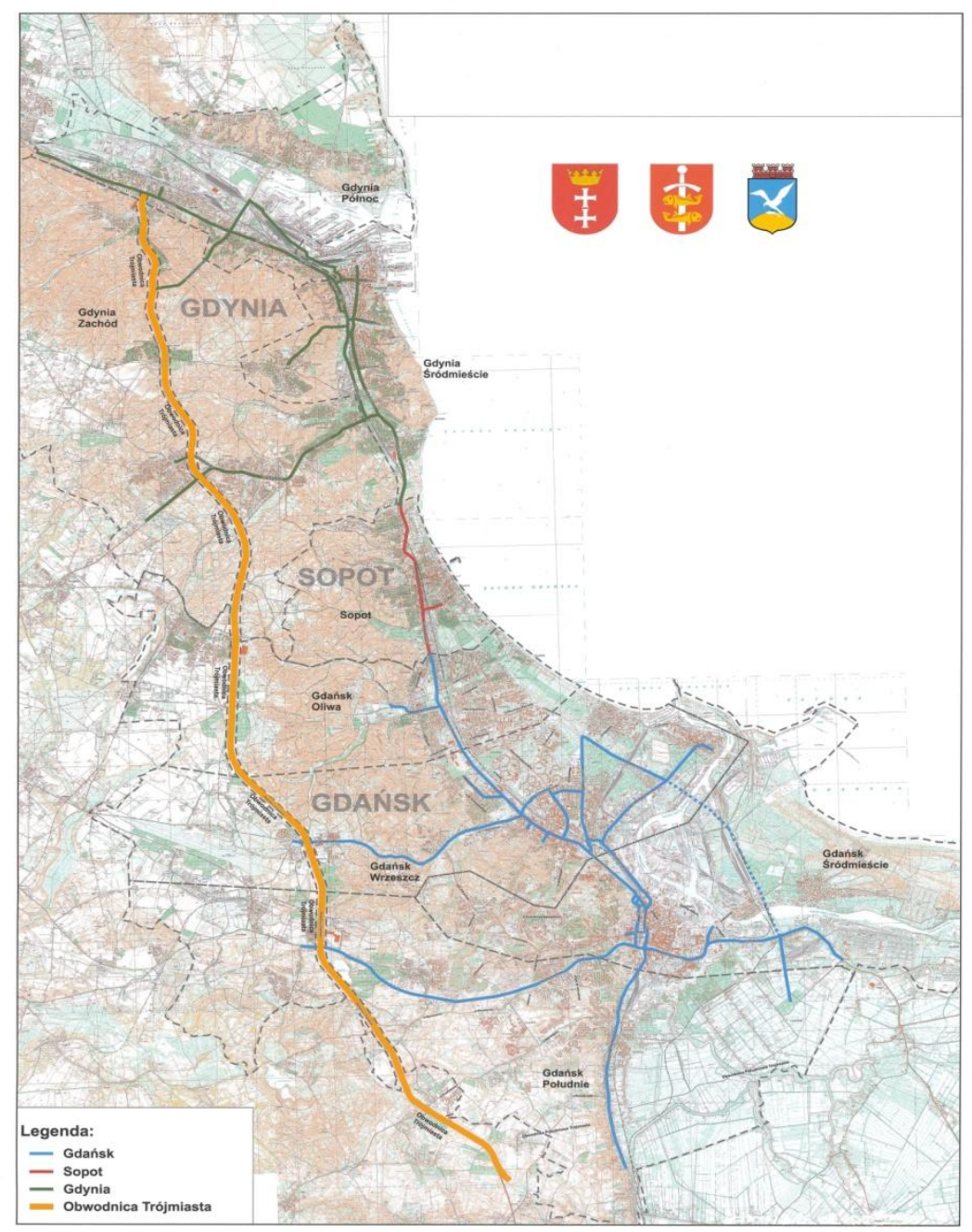

Fig. 1 The streets of the Tri-City included in TRISTAR system.

The architecture defines a four-level, hierarchical functional structure (metropolitan, urban, zone and local management levels). The level of urban management, also called the strategic level or central management layer, covers urban traffic management in the Tri-City. Key demands will be implemented at this level in accordance with the transport policies of the cities that from part of the TriCity Conurbation. The primary function of the central level, physically located in two Transport Management Centres (in Gdansk and Gdynia) is the integration of all the systems (subsystems) included in the on-going stage of TRISTAR system implementation (Fig. 2) [4]. 


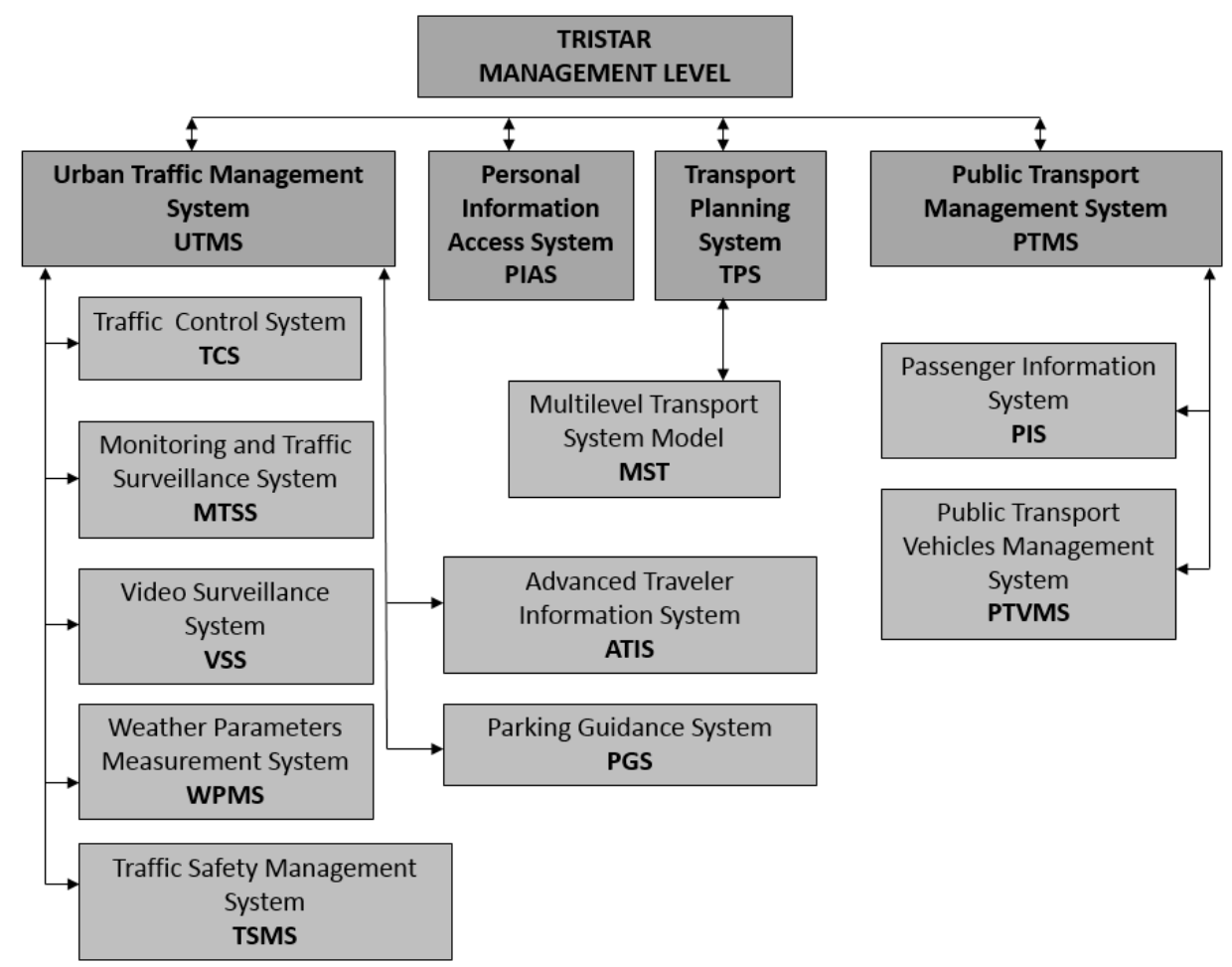

Fig. 2 The general functional structure of TRISTAR system implementation.

The integration within TRISTAR will be achieved through dedicated hardware and software, a common data network and a common database to enable the mutual processing of information provided by the Urban Traffic Management System (UTMS), the Public Transport Management System (PTMS) and Transport Planning System (TPS). The use of hierarchical and modular structure of the system will allow for the expansion of TRISTAR in the future through the addition of new components of implemented subsystems and new functional subsystems and modules. The main task of the central system is the integration of systems, subsystems and modules through the collection, processing and distribution of data [4]. The Traffic Control System (TCS) is an element (subsystem) of UTMS. TCS enables adaptive control of traffic signals at 150 junctions in the Tri-City. Control parameters (cycle length, the split of green and offsets) at junctions are determined automatically for each sub-area by the central level. For this purpose, the BALANCE control system (balancing adaptive network control method) [5], [6] is implemented. BALANCE uses genetic algorithms which help to minimise the loss of time, number of vehicle stops and length of queues in the designated area. At the same time the EPICS local control system takes control over each single junction. The EPICS model-based traffic adaptive control method optimizes on the basis of 
Reliability and safety as an objective of intelligent transport systems in urban areas Niezawodność i bezpieczeństwo celem wdrażania inteligentnych systemów...

the current traffic using the status changes of the detectors (a deterministic model similarly to the TRANSYT model that has been developed for EPICS)[7]. Signals at junctions according to the defined weights may be controlled more locally (EPICS) or taking into consideration the parameters of the traffic in the designated area of the street network (BALANCE). TCS controls traffic with priorities for public transport vehicles. For this purpose appropriate detection equipment in public transport vehicles and solutions for vehicle location provided in PTVMS are used. This helps to address the priorities for public transport vehicles on the basis of vehicle delays in relation to the timetable. The primary function of the MTSS is to deliver and collect specific information regarding the number and type of vehicles moving in the area covered by the system in the data warehouse. This module primarily uses traffic measurement stations and other detectors installed at junctions and in the street network. MTSS provides data on e.g. the level of service and average speed of vehicles. Video Surveillance System (VSS) provides images from cameras (CCTV) placed at critical points of the road network. The main task of WPMS is to collect and store data in databases and data warehouses and provide information on weather conditions in the Tri-City Conurbation. PGS provides information about the availability of parking places in chosen areas of cities (car parks). Based on the information supplied by devices counting vehicles in car parks, the system determines the number of places available and provides information to Variable Message Signs. The system must provide current data on the availability of parking in order to allow their use by other subsystems (in particular by PIAS via the website). TSMS enables the implementation of features such as automatic supervision of the behaviour of road users (i.e. speeding and running a red light) and smooth and early detection of dangerous situations and road incidents, rapid reporting of hazardous incidents and road accidents to emergency and road services. The main function of the Traveller Information System (ATIS) is to process data, collected in databases and TRISTAR data warehouse and transfer them in the form of textual and graphical information to road users through VMS and VMB. The system can manage data provided by other systems or by the operator. The system is a primary source of knowledge about the road in terms of traffic volume, current and predicted traffic conditions, incidents and planned obstructions, weather on the roads and warnings of hazardous weather conditions for traffic. Information obtained from ATIS is used by PIAS (presented on the Internet portal and transferred in the form of radio communications in the future as well as through other media - such as satellite navigation) [4], [8].

\section{ITS measures to improve the reliability and safety}

In system engineering, reliability may be defined as the degree of stability of the quality of service that a system normally offers [9]. In a transport system such as a road network, there are two key elements that contribute to the level of service: travel demand flows and physical network/transport services (the supply of transport system). The degree of stability of the transport network system can be 
referred to as the ability of the network to meet the expected goals under different circumstances (e.g. variability in flows and physical network capacities). For example, it might be expected that the network should be able to cope with the variation in demand over different days of the week by maintaining a constant average travel time between different origin-destination pairs [10]. Alternatively, it might be required that the network is able to maintain at least one possible travel path between all OD (Origin-Destination) pairs under unexpected phenomena ranging from unexpected incidents (e.g. accidents) to environmental factors, which cause some link failures [11]. Clearly, many other definitions are possible [12]. A common theme running through the extension of techniques for reliability analysis will be seen to be the representation of (stochastic) uncertainty in the level-of-service provided by the network to the travellers using it, yet one may identify at least five classes of method that have arisen [13]:

- connectivity reliability, examining the probability of complete failure of an OD movement caused by link capacity failures,

- travel time reliability, estimating the distribution of OD or network travel times under variations in link travel times, the OD matrix and/or link capacities,

- behavioural reliability, modelling the effect on mean behaviour and network performance of drivers' behavioural response to travel time variability,

- capacity reliability, which aims to determine the range of OD demands that allow the network to function within its capacity,

- vulnerability analysis, based on identifying vulnerable elements of a network under pessimistic assumptions.

Reliability is regarded as a desirable transport network attribute. Technically, a reliable system is one that performs its required functions under stated conditions for a specified period of time. Under this definition, a road system that becomes congested with traffic during peak hour, significantly reducing speeds, could be regarded as unreliable, or $50 \%$ reliable, depending on the conditions specified. An alternative definition of reliability draws on the attribute of predictability. In this context, a congested road system where the speeds at different times of day and different days of the week are consistent, and hence predictable, would be ranked as highly reliable [14]. In both cases, ITS solutions are used that on the one hand, allow the determination of the state of the transport network, and on the other, raise the level of safety and improve the effectiveness of the transport system. Table 1 presents the possible positive impact of the UTMS subsystems within TRISTAR on the level of safety and increase in the efficiency of the transport systems [2], [15], [16], [17].

Reliability is found as one of the most important attributes of public transport quality. Schedule reliability can be defined as the ability of a public transport system to follow the posted timetable. The main task of the Public Transport Vehicles Management System (PTVMS) is to keep regularity and punctuality. The system helps to take appropriate responses of public transport vehicles to disruption in the street network (using TPS). 
Reliability and safety as an objective of intelligent transport systems in urban areas Niezawodność i bezpieczeństwo celem wdrażania inteligentnych systemów...

Table 1. Impact of TRISTAR UTMS subsystems on the level of safety and the efficiency of the transport system.

\begin{tabular}{|c|c|c|}
\hline $\begin{array}{l}\text { Subsystem and functions } \\
\text { carried out }\end{array}$ & $\begin{array}{l}\text { Efficiency of transport } \\
\text { system }\end{array}$ & Level of traffic safety \\
\hline $\begin{array}{l}\text { TCS } \\
\text { - adaptive control of traffic } \\
\text { signals (locally and territo- } \\
\text { rially - in the designated } \\
\text { area and individual } \\
\text { junctions) } \\
\text { - priorities for public trans- } \\
\text { port vehicles. }\end{array}$ & $\begin{array}{l}\text { - minimisation of the loss of } \\
\text { time, number of vehicle } \\
\text { stops and length of queues, } \\
\text { - minimisation of travel time } \\
\text { in network and OD } \\
\text { relations, } \\
\text { - degree of saturation } \\
\text { (capacity) optimization, } \\
\text { - reduction of public trans- } \\
\text { port vehicle delays in } \\
\text { relation to the timetable. }\end{array}$ & $\begin{array}{l}\text { - improving traffic condi- } \\
\text { tions in the street network } \\
\text { by optimizing the control } \\
\text { parameters (especially } \\
\text { delays at junctions) may } \\
\text { help to reduce the number } \\
\text { of vehicles or pedestrians } \\
\text { to run a red light, } \\
\text { - homogenization of traffic } \\
\text { flow (in terms of speed) by } \\
\text { optimizing offsets at } \\
\text { junctions. }\end{array}$ \\
\hline $\begin{array}{l}\text { PGS } \\
\text { - informing drivers about } \\
\text { available parking spaces } \\
\text { and giving guidance for } \\
\text { parking } \\
\text { - transport demand manage- } \\
\text { ment (regulating and } \\
\text { restraining car use). }\end{array}$ & $\begin{array}{l}\text { - reduction in total network } \\
\text { travel time (reduced } \\
\text { congestion), } \\
\text { - reduction in travel time of } \\
\text { drivers searching for a } \\
\text { parking space, } \\
\text { balancing of parking } \\
\text { demand and supply. }\end{array}$ & $\begin{array}{l}\text { - improving the level of } \\
\text { safety by reducing the } \\
\text { distraction of drivers } \\
\text { looking for available } \\
\text { parking spaces. }\end{array}$ \\
\hline $\begin{array}{l}\text { TSMS } \\
\text { automatic supervision of } \\
\text { the behaviour of road } \\
\text { users (speeding and } \\
\text { running a red light), } \\
\text { - early detection of unexpected, } \\
\text { irregular incidents including } \\
\text { accidents (Incident Detection } \\
\text { Module) and immediately } \\
\text { informing emergency and } \\
\text { road services. }\end{array}$ & $\begin{array}{l}\text { - homogenization of traffic } \\
\text { flow (in terms of speed), } \\
\text { - faster elimination of } \\
\text { congestion and restoration } \\
\text { of normal traffic in case of } \\
\text { an incident (when } \\
\text { combined with ATIS), } \\
\text { - incident management } \\
\text { systems contribute to } \\
\text { shortening the travel time } \\
\text { of emergency services by } \\
\text { about } 45 \% \text {. }\end{array}$ & $\begin{array}{l}\text { - implementation of auto- } \\
\text { mated traffic enforcement } \\
\text { contributes to a reduction } \\
\text { in the number of accidents } \\
\text { by } 20-80 \% \text {, } \\
\text { - reduction in accident } \\
\text { severity due to faster } \\
\text { access of emergency } \\
\text { services (possibility of } \\
\text { reducing the response time } \\
\text { and the intervention of } \\
\text { rescue services by 20- } \\
40 \% \text { ), } \\
\text { - reduction in the number of } \\
\text { secondary accidents of } 7-50 \% \text {. }\end{array}$ \\
\hline $\begin{array}{l}\text { ATIS } \\
\text { - informing drivers about } \\
\text { delays, congestion, } \\
\text { incidents, road works, } \\
\text { alternative routes, } \\
\text { - speed management (taking } \\
\text { into account weather and } \\
\text { traffic conditions) } \\
\text { - transport demand } \\
\text { management (regulating } \\
\text { and restraining car use). }\end{array}$ & $\begin{array}{l}\text { - faster elimination of } \\
\text { congestion and restoration } \\
\text { of normal traffic condition } \\
\text { in case of an incident (when } \\
\text { combined with Incident } \\
\text { Detection Module), } \\
- \text { balancing of traffic } \\
\text { demand and supply on } \\
\text { alternative } \\
\text { (minimisation of overall and } \\
\text { OD travel time, cost). }\end{array}$ & $\begin{array}{l}\text { - homogenization of traffic } \\
\text { flow in terms of speed } \\
\text { (when combined with } \\
\text { WPMS, MTSS, TSMS), } \\
\text { - reduction in speed taking } \\
\text { into account weather and } \\
\text { traffic conditions (reduction } \\
\text { in primary and secondary } \\
\text { accidents, reduction in } \\
\text { accident severity). }\end{array}$ \\
\hline
\end{tabular}


The Public Transport Vehicle Location Module provides information on the geographical location of all public transport vehicles currently in motion on the basis of the information provided with on-board computers equipped with a GPS satellite navigation system. Waiting time reliability is defined as the probability that the passengers' average waiting time is less than a given threshold [18]. This definition takes on a new meaning because the Passenger Information System (PIS) keeps passengers informed about the actual departure time of vehicles via variable message passenger information boards at bus stops as well as via passenger information terminals (trip planners) available at the transfer nodes and in shopping centres. Passenger information terminals and a web portal help to plan the trip taking into account delays of public transport vehicles.

The Personal Information Access System (PIAS) provides information about traffic conditions before and during travelling both by private vehicle drivers and passengers of public transport vehicles. As part of the system, an Internet portal will be launched, the same for all the cities, where the information will be displayed. The Internet service will help to schedule the shortest and/or quickest route, based on public transport timetables (including local trains) and information about delays from PTVMS and other subsystems. Such information may change the transport behaviour of travellers (in the network as a whole and for individual OD relations - for redirecting travel paths and changing demand).

The Transport Planning System (TPS) is assisted by tools (software packages) that are useful in the planning of transport systems, analysis of traffic conditions and tests and simulation of new planned traffic layouts. As part of the TPS, a multilevel model of transport systems (MST) is implemented, which supports the development of analysis and traffic forecasts for planning purposes. It also supports the needs of the current traffic management. MST uses data necessary for calibration or simulation directly from the databases and data warehouse of the TRISTAR system [4], [8]. The TPS makes changes in the transport system more predictable and controllable which can improve the level of network reliability.

\section{Conclusions}

Defining and controlling transport network reliability (and its degree) is extremely difficult due to the different classes of network reliability and various types of users often competing with each other. In addition, a higher level of safety may decrease levels of reliability (capacity, travel times). The key words characterizing reliability seem to be acceptable, predictable and controllable. Planning reliability levels (including political decisions) is also important. The effect may be that higher redundancy is incorporated into e.g. planned travel times, to minimise the impact of unanticipated delays on scheduled activities. This may then lead to a 
Reliability and safety as an objective of intelligent transport systems in urban areas Niezawodność i bezpieczeństwo celem wdrażania inteligentnych systemów...

worsening of the welfare of society as a whole. Commercial organisations also often experience the problem of unpredictability in transport costs due to the uncertainty in the transport system, as a consequence, the risk may be transferred to the price of commodities [12]. While other services (electricity, water supply, communication networks) can be restored in a relatively short period of time, the restoration of transport systems depends highly on the accessibility of failure points using the transport infrastructure including ITS solutions. The majority of reliability indicators monitor the performance characteristics of the whole system rather than the satisfaction of different users' needs (e.g. for a network provider or operator, the focus is on system robustness/vulnerability, while for a network user, the focus is on the variability of travel times experienced by the user) [14]. The network user may be a pedestrian, driver (private or freight transport), cyclist, passenger of public transport or someone taking a multimodal journey. A greater efficiency of the transport system and a higher level of safety can be achieved through the use of complex solutions, such as the ITS. In view of this, the Gdansk University of Technology conducts research on new solutions of ITS within the framework of the research project CIVITAS DYN@MO. Within this project a multilevel model of transport systems (MST) has been developed, which will increase the predictability in the operational management of transport. Measures such as incident detection will also contribute to increased efficiency of the system and increase the level of safety.

The research is conducted under the CIVITAS-DYN@MO project "DYNamic citizens@ctive for sustainable MObility" co-financed by the European Union, under the EU's $7^{\text {th }}$ Framework Programme.

\section{References}

[1] Oskarbski J.: Perspectives of Telematics Implementation in Tri-City Transport Systems Management and Planning, Communications in Computer and Information Science (Modern Transport Telematics), Vol. 239, pp 233-240, 2011.

[2] US DOT: Intelligent Transportation Systems, Joint Program Office, Knowledge Resources -Available at: http://www.Itsbenefits.Its.Dot.Gov/Its/ Benecost.Nsf/Bylink/Benefitsabout.

[3] Jamroz K., Oskarbski J.: ITS in Tri-City Conurbation - Implementation of TRISTAR System. Advances in transport systems telematics, pp 231-238, 2008. 
[4] Oskarbski J.: Intelligent Transportation Systems in the management of transportation in the Tri-City - TRISTAR system functional structure. Przegląd Komunikacyjny No.7-8, pp. 26-31, 2011.

[5] Friedrich B., \& Mertz J.: Abschlußbericht Munich COMFORT Arbeitsbereich 444, Städtische Verkehrssteuerung. München: Fachgebiet Verkehrstechnik und Verkehrsplanung, TU-München, 1996.

[6] Friedrich B., Mertz J., Ernhofer O., Clark M., Toomey C., McLean T., et al.: TABASCO Deliverable 9.4: Urban Traffic Control with PT Priority: Final Evaluation Report. Brussel, 1998.

[7] Mertz J.: Ein mikroskopisches Verfahren zur verkehrsadaptiven Knotenpunktsteuerung mit Vorrang des öffentlichen Verkehrs (dissertation). Fachgebiet Verkehrstechnik und Verkehrsplanung Univ. Prof. Dr./UCB Hartmut Keller Technische Universität München, 2000.

[8] Oskarbski J., Jamroz K., Birr K.: Application of Multi-Level Transport Model for the TRISTAR System. Conference paper. DTA-5th International Symposium on Dynamic Traffic Assignment, Salerno Italy, June 17th - 19th, 2014.

[9] Bell M.G.H., Iida Y: Transportation Network Analysis. John Wiley and Sons, Chichester, UK, 1997.

[10] Ang A. H.-S., Tang W. H.: Probability concepts in engineering planning and design. Vol. II: Decision, risk and reliability, Wiley, New York, 1990.

[11] Iida Y., Wakabayashi H.: An approximation method of terminal reliability of road network using partial minimal path and cut set. Proceedings of the 5 th WCTR, Vol. 4, pp. 367-380, 1990.

[12] Watling D., Sumalee A., Connors R., Balijepalli C.: Advancing Methods for Evaluating Network Reliability. A Department for Transport "New Horizons" Project: Final Report. Institute for Transport Studies, University of Leeds, 2004. http://webarchive.nationalarchives.gov.uk/20070306100043/http:/www. dft.gov.uk/pgr/economics/rdg/jtv/amenr/advancingmethodsforevaluatin3080

[13] Watling D.: Modelling And Evaluation Of Reliability Impacts In Road Networks: Concepts And Methods For Traffic Assignment Models. Institute for Transport Studies, University of Leeds, Leeds, UK. Association for European Transport and contributors 2008. http://abstracts.aetransport.org /paper/download/id/3050

[14] OECD: Improving Reliability on Surface Transport Networks. Summary document. Transport Research Centre. OECD/ITF, 2009.

[15] Bunch J., Burnier C., Greer E., Hatcher G., Jacobi A., Kabir F., Lowrance C., Mercer M., Wochinger K.: Intelligent Transportation Systems Benefits, Costs, Deployment and Lessons Learned Desk Reference 2011 UPDATE. RITA Intelligent Transportation Systems Joint Program Office. Final Report September 2011. FHWA-JPO-11-140. 
Reliability and safety as an objective of intelligent transport systems in urban areas Niezawodność i bezpieczeństwo celem wdrażania inteligentnych systemów...

[16] McDonald M., Keller H., Klijnhout J., Mauro V., Hall R., Spence A., Hecht C., Fakler O.: Intelligent Transport Systems in Europe. Opportunities for Future Research. World Scientific, 2006.

[17] Oskarbski J., Jamroz K.: Inteligentne Systemy Transportu ITS na drogach szybkiego ruchu. Rozdz. 12 w: Węzły drogowe i autostradowe. Praca zbiorowa pod redakcją R. Krystka. WKŁ, Warszawa 1998, str. 428 -468.

[18] Yin Y., Lam W.H.K., Ieda H.: Reliability Assesment on Transit Network Services. The Network Reliability of Transport. Pergamon, 2003.

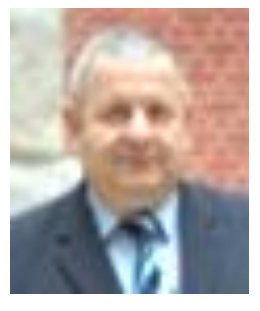

Kazimierz Jamroz. Associate professor in the Department of Civil Engineering at the Gdansk University of Technology. As head of the research team and project team he developed models of geometrical effects on the conditions of roads and road safety, safety management methods of transport and road traffic, national, regional and county road safety programmes, concepts of ITS and traffic management systems, numerous studies and traffic forecasts.

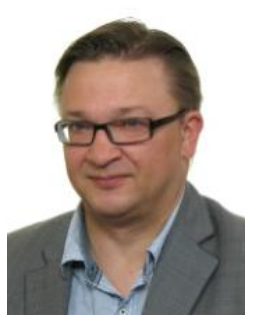

Jacek Oskarbski. Assistant professor (D.SC.Eng.) in the Department of Civil Engineering at the Gdansk University of Technology. His main research areas are: traffic modelling and forecasting, transport planning, intelligent transport systems, traffic engineering and mobility management. Since 2007, he has been a member of the board of the Association of Intelligent Transport Systems, "ITS Poland". Researcher in many national and international projects i.e. CIVITASDYN@MO,ZEUS, FLOW,BUSTRIP. 